\title{
Pharmacokinetics of Marbofloxacin Following Single and Repeated Dose Intravenous Administration in Broiler Chickens
}

\author{
H. B. Patel*, U. D. Patel, C. M. Modi and D. H. Bhadarka
} Department of Veterinary Pharmacology and Toxicology, College of Veterinary Science and
Animal Husbandry, Junagadh Agricultural University, Junagadh-362001, India

*Corresponding author

\section{A B S T R A C T}

\section{Keywords}

Marbofloxacin, Pharmacokinetics, Pharmacodynamics, Single and repeated dose,I.V. administration, Broiler chickens,HPLC with UV detector

Article Info

Accepted:

20 May 2018

Available Online:

10 June 2018
Marbofloxacin is a third generation fluorinated quinolone, exclusively used in veterinary medicine. The dosage regimen of drugs can be optimized by their pharmacokinetic studies. Pharmacokinetics of marbofloxacin after repeated intravenous (i.v.) administration was not reported earlier in any veterinary species. Hence, present study was planned to investigate the pharmacokinetics of marbofloxacin following single $(5 \mathrm{mg} / \mathrm{kg})$ and repeated dose $(5$ $\mathrm{mg} / \mathrm{kg}$, for 5 days) i.v. administration in broiler chickens. Following i.v. administration of marbofloxacin, the mean values of elimination half-life $\left(\mathrm{t}_{1 / 2 \beta}\right)$ (single dose: $5.55 \pm 0.67$; repeated dose: $5.12 \pm 0.25 \mathrm{~h}$ ), volume of distribution at pseudo equilibrium $\operatorname{Vd}_{(\text {area }}$ (single dose: $1.49 \pm 0.12$; repeated dose: $1.37 \pm 0.08 \mathrm{~L} / \mathrm{kg}$ ) and area under curve (AUC) (single dose: $26.80 \pm 2.08$; repeated dose: $27.60 \pm 2.57 \mu \mathrm{g} . \mathrm{h} / \mathrm{mL}$ ) were found in the present study. Significant difference in total body clearance $\left(\mathrm{Cl}_{\mathrm{B}}\right)$ and mean residence time (MRT) were not observed after single or repeated dose i.v. administration. The mean ratio of $\mathrm{K}_{12} / \mathrm{K}_{21}$ was significantly $(\mathrm{p}<0.01)$ higher after repeated i.v. administration compare to single dose. The plasma drug concentration greater than $0.10 \pm 0.02$ and $0.15 \pm 0.03 \mu \mathrm{g} / \mathrm{mL}$ (therapeutically effective concentration) were maintained up to $24 \mathrm{~h}$ after single and repeated drug administration, respectively. Marbofloxacin following single and repeated dose i.v. administration $(5 \mathrm{mg} / \mathrm{kg})$ showed favorable pharmacokinetic profiles in chickens.

\section{Introduction}

Poultry industry is one of the fastest growing sectors of Indian agriculture with annual growth rates of $5.57 \%$ and $11.44 \%$ in egg and broiler production, respectively (Anonymous, 2012). Bacterial infection like colibacillosis, salmonellosis, pasteurellosis, campylobacterosis, mycoplasmosis, tuber- culosis, psittacosis, infectious coryza and coccidiosis were important threats to poultry industry (Hasan et al., 2010). Therapeutic and prophylactic use of antibiotics has allowed poultry production to achieve significant improvement by enhancing growth rate, feed efficiency and reducing mortality. Marbofloxacin is a third generation, fluorinated quinolone, exclusively used for 
veterinary medicine (Brown, 1996). It exhibits bactericidal action by targeting the bacterial DNA topoisomerases II (gyrase) and IV, which are responsible for supercoiling of DNA (Drlica and Zhao, 1997). Marbofloxacin having broad spectrum of antimicrobial activity against gram-negative, some grampositive bacteria and mycoplasma spp. In vivo and in vitro efficacy against Staphylococcus intermedius, Escherichia coli, Proteus mirabilis, Pseudomonas spp., Pasteurella multocida, and Mannheima haemolytica have also been reported (Spreng et al., 1995; Shojaee and Lees, 1997).

Fluoroquinolones are intensively used in poultry industry and facilitated better treatment of several infectious bacterial diseases. The use of these drugs must comply with strict withdrawal periods, doses and duration of treatment (Gouvea et al., 2015). Therapeutic effective dosage regimen can be determined by investigation of pharmacokinetic properties of drugs. Marbofloxacin is commonly used in broiler chickens, however pharmacokinetics of marbofloxacin after repeated intravenous (i.v.) administration was not studied yet. Hence present study was planned to investigate the pharmacokinetics of marbofloxacin following single $(5 \mathrm{mg} / \mathrm{kg})$ and repeated dose $(5 \mathrm{mg} / \mathrm{kg}$, for 5 days) i.v. administration in broiler chickens to generate valuable information for designing effective dosage regimen in life threatening condition.

\section{Materials and Methods}

\section{Experimental animals}

The experiment was carried out on 12 broiler chickens of strain 'Cobb 400' which were obtained from Venky's hatcheries Pvt. Ltd., Anand, Gujarat. Experimental protocol was approved by Institutional Animal Ethics Committee (IAEC), College of Veterinary
Science and Animal Husbandry, Junagadh (Protocol No.: JAU/JVC/IAEC/SA/22/2017). Day old broiler chickens were kept in broiler house and reared up to the age of 3 weeks and vaccination schedule was followed as per standard managemental practices to control common infectious diseases of birds. During entire study period the broiler chickens were housed in the cool environment of winter season (20 to $30{ }^{0} \mathrm{C}$ temperature). Broiler starter and finisher feed of BIS (9862-1992) specification (Simran Feeds Pvt. Ltd, Indore, Madhya Pradesh, India) and reverse osmosis drinking water were provided ad libitum to chickens.

\section{Drugs and chemicals}

Marbofloxacin technical grade pure powder was obtained from Sigma Aldrich, Bangalore, India. Marbofloxacin tablet $50 \mathrm{mg}$ and marbofloxacin injection $100 \mathrm{mg} / \mathrm{mL}$ (Intas Pharmaceuticals Ltd., Ahmedabad, India) were used in study. Water, acetonitrile and formic acid of HPLC grade were purchased from Merck India Ltd., Mumbai.

\section{Experimental design}

Based on body weight, 12 broiler chickens of 3 weeks of age were randomly divided in two groups. I.V. doses of marbofloxacin $(5 \mathrm{mg} / \mathrm{kg})$ were administered through right or left jugular vein alternatively for 5 consecutive days. Blood samples (approximately, $0.50 \mathrm{~mL}$ ) were collected through IV catheter $(26 \mathrm{G} \mathrm{x} 3 / 4 ; 0.6 \mathrm{x}$ $0.19 \mathrm{~mm}$; flow $15 \mathrm{~mL} / \mathrm{min}$ ) fixed in wing vein in $2 \mathrm{~mL}$ heparinized centrifuge tubes. Following i.v. administration of drug, at day $1^{\text {st }}$ and day $5^{\text {th }}$, blood samples were collected at 0 minute (before drug administration) 2 $(0.033 \mathrm{~h}), 5(0.0833 \mathrm{~h}), 15(0.25 \mathrm{~h})$ and 30 (0.5 h) minutes and at 1, 2, 4, 8, 12 and $24 \mathrm{~h}$. Plasma was separated from each sample after centrifugation at $12000 \mathrm{rpm}$ for 10 minutes at $4^{\circ} \mathrm{C}$ (Eppendorf 5430 R, Germany). The 
plasma samples were transferred to cryo-vials ( $2 \mathrm{~mL}$ capacity) and then stored at $-80{ }^{\circ} \mathrm{C}$ until assayed for marbofloxacin concentration using HPLC procedure which was carried out within a week.

\section{HPLC analysis}

The high performance liquid chromatography apparatus (LC-2010 CHT, Schimadzu, Japan), comprising quaternary gradient delivery pump (LC-2010) and UV detector was used for assay. Chromatographic separation was performed using reverse phase Zorbax Eclipse $\mathrm{XDB} \mathrm{C}_{18}$ analytical column $(4.6 \mathrm{~mm} \times 250$ $\mathrm{mm}$; ID 5-micron) at $30{ }^{\circ} \mathrm{C}$. The HPLC data integration was performed using LC solution software (Shimadzu).

The plasma samples were analyzed for marbofloxacin concentration using a slight modification of method described by Carpenter et al., (2006). Quantification of marbofloxacin in plasma samples was done by reference to the resultant standard curve. The assay was sensitive, reproducible and linearity was observed from 0.049 to $50 \mu \mathrm{g} / \mathrm{mL}$ with mean correlation coefficient $(r)>0.999$. The lower limit of quantification of the drug was $0.049 \mu \mathrm{g} / \mathrm{mL}$ with a coefficient of variation of less than $9.43 \%$.

The mobile phase was a mixture of $10 \mathrm{mM}$ formic acid in HPLC water and acetronirile (80:20). Mobile phase was filtered by $0.45 \mu$ size filter (Millipore India Pvt., Ltd., Bangalore) and degassed by ultra-sonication. The mobile phase was pumped into column at a flow rate of $0.75 \mathrm{~mL} / \mathrm{min}$ at $30{ }^{\circ} \mathrm{C}$ temperature. The effluent was monitored at $295 \mathrm{~nm}$ wavelength. Plasma samples $(250 \mu \mathrm{L})$ were precipitated by adding $250 \mu \mathrm{L}$ of perchloric acid $(0.8 \mathrm{M})$ and vortexed for 10 minutes. Then samples were centrifuged at $12000 \mathrm{rpm}$ for $10 \mathrm{~min}$ and clear supernatant was collected in to HPLC vials and $20 \mu \mathrm{L}$ of sample was injected in to HPLC system through auto sampler.

\section{Pharmacokinetic and statistical analysis}

Pharmacokinetic parameters were calculated as per standard methods (Baggot, 1977; Gibaldi and Perrier, 1982). The data obtained for pharmacokinetic parameters were presented as Mean \pm S. E. and analysed statistically using paired sample $t$-test. Where $\mathrm{p}$ $\leq 0.05$ was considered as statistically significant and $\mathrm{p} \leq 0.01$ was considered as statistically highly significant.

\section{Results and Discussion}

The plasma concentrations $(\mu \mathrm{g} / \mathrm{mL})$ of marbofloxacin in relation to time in healthy broiler chickens following single $(5 \mathrm{mg} / \mathrm{kg})$ and repeated dose i.v administration $(5 \mathrm{mg} / \mathrm{kg}$, daily for 5 days) are depicted in table 1, while semilogarithmic plot of the same is presented in figure 1. Following i.v. administration, the initial plasma marbofloxacin concentrations were $6.78 \pm 0.28$ and $17.72 \pm 5.28 \mu \mathrm{g} / \mathrm{mL}$ after single and repeated administration, respectively. The plasma concentration at 2 min after repeated i.v. administration of marbofloxacin was significantly $(\mathrm{p}<0.01)$ higher than single dose administration.

The plasma concentrations of marbofloxacin of $\geq 0.10 \pm 0.02$ (after single dose) and $\geq 0.15$ $\pm 0.03 \mu \mathrm{g} / \mathrm{mL}$ (after repeated dose) were maintained up to $24 \mathrm{~h}$ after drug administration. This covers $\mathrm{MIC}_{90}$ value of $0.125-0.20 \mu \mathrm{g} / \mathrm{mL}$ against most common $E$. coli and other gram-negative bacterial infections except $P$. aeurgenosa in chickens and other birds (Spreng et al., 1995; Haritova et al., 2006).

The pharmacokinetic parameters of marbofloxacin after its single $(5 \mathrm{mg} / \mathrm{kg})$ and repeated dose $(5 \mathrm{mg} / \mathrm{kg}$, daily for 5 days $)$ i.v. 
administration in broiler chickens are depicted in table 2. After single and repeated i.v. administration, the mean values of distribution rate constant $(\alpha)$ were $6.30 \pm 1.79$ and $5.82 \pm$ $0.81 \mathrm{~h}^{-1}$, respectively and elimination rate constant $(\beta)$ of $0.13 \pm 0.02$ and $0.14 \pm 0.01 \mathrm{~h}^{-1}$, respectively observed in the present study. After single i.v. administration of marbofloxacin, similar values of distribution and elimination rate constants ( $\alpha$ : $5.46 \pm$ 0.61 and $\left.\beta: 0.13 \pm 0.02 \mathrm{~h}^{-1}\right)$ were reported in broiler chickens (Anadon et al., 2002). Findings of present study, indicated that the drug was rapidly distributed in the body fluids and then relatively slowly eliminated from the body in broiler chickens after single and repeated i.v. administration.

Following single and repeated dose i.v. administration of marbofloxacin, the elimination half-lifes $\left(\mathrm{t}_{1 / 2 \beta}\right)$ were $5.55 \pm 0.67$ and $5.12 \pm 0.25 \mathrm{~h}$, respectively found in the present study. After single i.v. administration, proximate values of $t_{1 / 2 \beta}$ of $5.26 \pm 0.66 \mathrm{~h}$ has been reported in broiler chickens (Anadon et al., 2002) and6.4 $\pm 0.08 \mathrm{~h}$ in foals (Tohamy and El-Gendy, 2013). Whereas, lower values of $t_{1 / 2 \beta}$ were found $(1.47 \pm 0.31 \mathrm{~h})$ in ostriches (De Lucas et al., 2005), $(2.83 \pm 0.28 \mathrm{~h})$ Muscovy ducks (Goudah and Hasabelnaby, 2010), and (4.03 $\pm 0.08 \mathrm{~h})$ Japanese quails (Aboubakr and Abdelazem, 2015). In contrast to this, Schneider et al., (2004) observed little high value of $t_{1 / 2 \beta}$ of $6.27 \pm 2.80 \mathrm{~h}$, after repeated i.m. administration of marbofloxacin ( $2 \mathrm{mg} / \mathrm{kg}$, for 3 days) in lactating cows. Lower elimination half-life in broiler chickens as compare to cows, might be due to difference in route of drug administration, $\mathrm{pH}$ of urine and inter-species differences. Haddad et al., (1985) stated that such variation were also related to assay methods used, the time between blood samplings, health status and age of the animals.

Table.1 Comparison of plasma concentrations of marbofloxacin $(5 \mathrm{mg} / \mathrm{kg})$ following single and repeated dose i.v. administration in broiler chickens

\begin{tabular}{|c|c|c|}
\hline \multirow{2}{*}{$\begin{array}{l}\text { Time after drug } \\
\text { administration (h) }\end{array}$} & \multicolumn{2}{|c|}{ Plasma concentration $(\mu \mathrm{g} / \mathrm{mL})$ Mean $\pm \mathrm{S} . \mathrm{E}$. } \\
\hline & $\begin{array}{l}\text { Marbofloxacin } \\
\text { Single dose }\end{array}$ & $\begin{array}{l}\text { Marbofloxacin } \\
\text { Repeated dose }\end{array}$ \\
\hline 0.0333 & $6.78 \pm 0.28$ & $17.72 \pm 5.28 * *$ \\
\hline 0.0833 & $5.37 \pm 0.13$ & $6.66 \pm 0.72$ \\
\hline 0.25 & $4.25 \pm 0.10$ & $4.50 \pm 0.27$ \\
\hline 0.5 & $3.73 \pm 0.11$ & $3.70 \pm 0.17$ \\
\hline 1 & $3.24 \pm 0.15$ & $3.32 \pm 0.17$ \\
\hline 2 & $2.72 \pm 0.14$ & $2.78 \pm 0.15$ \\
\hline 4 & $1.98 \pm 0.18$ & $2.02 \pm 0.12$ \\
\hline 6 & $1.55 \pm 0.17$ & $1.55 \pm 0.12$ \\
\hline 8 & $1.15 \pm 0.15$ & $1.11 \pm 0.17$ \\
\hline 12 & $0.65 \pm 0.08$ & $0.58 \pm 0.08$ \\
\hline 24 & $0.10 \pm 0.02$ & $0.15 \pm 0.03$ \\
\hline
\end{tabular}


Table.2 Pharmacokinetic parameters of marbofloxacin $(5 \mathrm{mg} / \mathrm{kg})$ following single and repeated dose i.v. administration in broiler chickens

\begin{tabular}{|c|c|c|c|}
\hline $\begin{array}{c}\text { Pharmacokinetic } \\
\text { Parameters }\end{array}$ & Unit & $\begin{array}{l}\text { Marbofloxacin } \\
\text { Single dose }\end{array}$ & $\begin{array}{l}\text { Marbofloxacin } \\
\text { Repeated dose }\end{array}$ \\
\hline $\mathrm{Cp}^{0}$ & $\mu \mathrm{g} / \mathrm{mL}$ & $7.16 \pm 0.57$ & $12.04 \pm 2.28 *$ \\
\hline $\mathbf{A}$ & $\mu \mathrm{g} / \mathrm{mL}$ & $3.62 \pm 0.40$ & $8.65 \pm 2.22$ \\
\hline $\mathbf{B}$ & $\mu \mathrm{g} / \mathrm{mL}$ & $3.54 \pm 0.24$ & $3.39 \pm 0.21$ \\
\hline$\alpha$ & $\mathrm{h}^{-1}$ & $6.30 \pm 1.79$ & $5.82 \pm 0.81$ \\
\hline $\boldsymbol{\beta}$ & $\mathrm{h}^{-1}$ & $0.13 \pm 0.02$ & $0.14 \pm 0.01$ \\
\hline$t_{1 / 2 \alpha}$ & $\mathrm{h}$ & $0.16 \pm 0.03$ & $0.13 \pm 0.02$ \\
\hline$t_{1 / 2 \beta}$ & $\mathrm{h}$ & $5.55 \pm 0.67$ & $5.12 \pm 0.25$ \\
\hline $\mathbf{A U C}_{(0-\infty)}$ & $\mu \mathrm{g} \cdot \mathrm{h} / \mathrm{mL}$ & $26.80 \pm 2.08$ & $27.60 \pm 2.57$ \\
\hline AUMC & $\mu \mathrm{g} \cdot \mathrm{h}^{2} / \mathrm{mL}$ & $182.75 \pm 16.68$ & $184.40 \pm 20.90$ \\
\hline $\mathbf{V} \mathbf{d}_{(\text {area) }}$ & $\mathrm{L} / \mathrm{kg}$ & $1.49 \pm 0.12$ & $1.37 \pm 0.08$ \\
\hline $\mathbf{V} \mathbf{d}_{(\mathrm{ss})}$ & $\mathrm{L} / \mathrm{kg}$ & $1.30 \pm 0.09$ & $1.24 \pm 0.10$ \\
\hline $\mathrm{K}_{12}$ & $\mathrm{~h}^{-1}$ & $3.05 \pm 0.99$ & $1.87 \pm 0.20$ \\
\hline $\mathbf{K}_{21}$ & $\mathrm{~h}^{-1}$ & $3.11 \pm 0.80$ & $0.43 \pm 0.06^{*}$ \\
\hline $\mathrm{K}_{12} / \mathrm{K}_{21}$ & Ratio & $0.91 \pm 0.09$ & $2.15 \pm 0.50 *$ \\
\hline $\mathrm{Cl}_{(\mathbf{B})}$ & $\mathrm{L} / \mathrm{h} / \mathrm{kg}$ & $0.19 \pm 0.02$ & $0.19 \pm 0.02$ \\
\hline MRT & $\mathrm{h}$ & $6.78 \pm 0.16$ & $6.63 \pm 0.15$ \\
\hline
\end{tabular}

Figure.1 Semilogarithmic plot of marbofloxacin concentration in plasma versus time following single and repeated dose $(5 \mathrm{mg} / \mathrm{kg}$, for 5 days) i.v. administration in broiler chickens

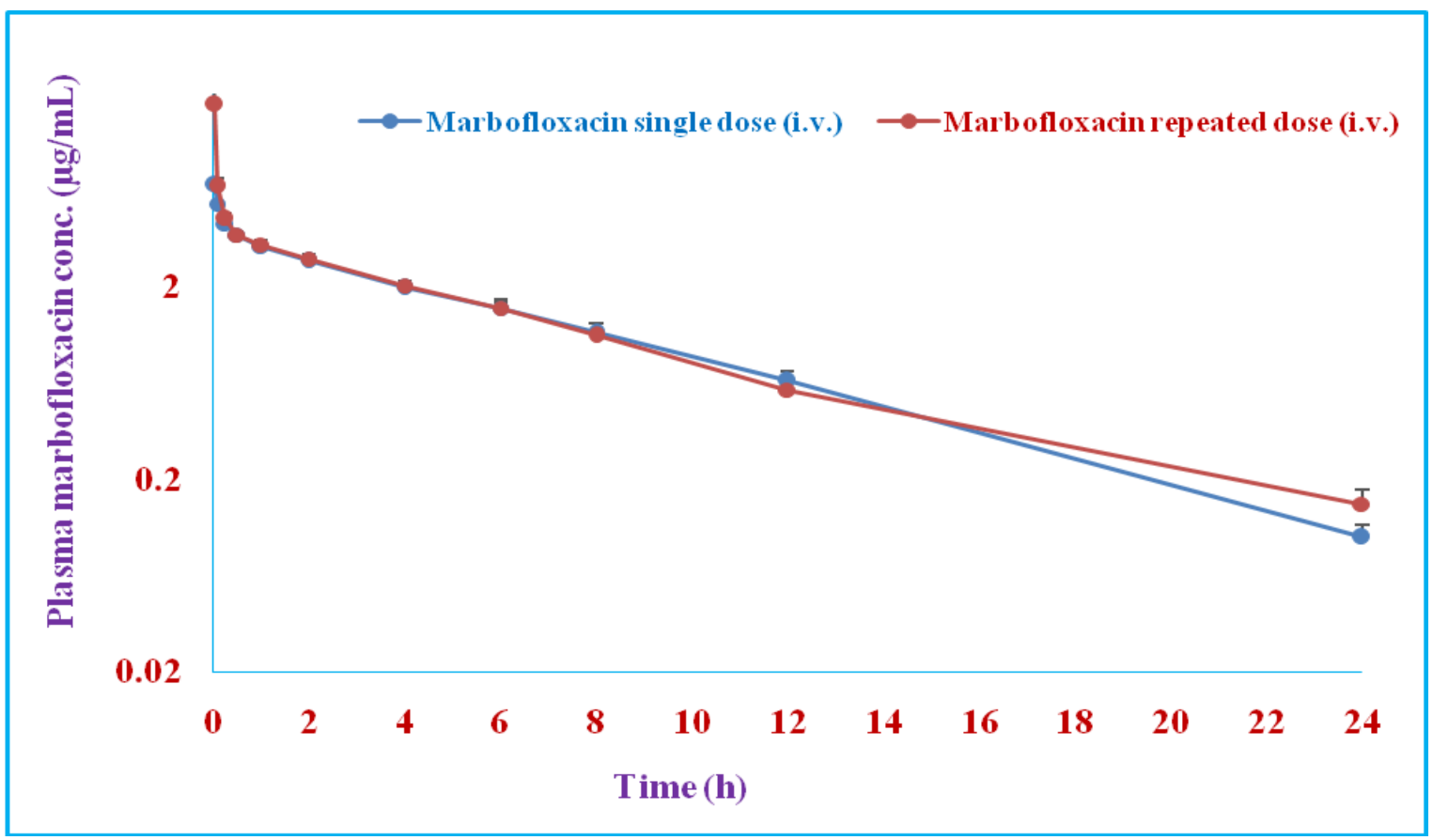


Following single and repeated dose i.v. administration of marbofloxacin, the volume of distribution $\mathrm{Vd}_{(\text {area })}$ were $1.49 \pm 0.12$ and $1.37 \pm 0.08 \mathrm{~L} / \mathrm{kg}$, respectively and AUC were $26.80 \pm 2.08$ and $27.60 \pm 2.57 \mu \mathrm{g} \cdot \mathrm{h} / \mathrm{mL}$, respectively in the present study. The marbofloxacin has large volume of distribution owing to its high lipid solubility and low plasma protein bindings which results in extensive penetration of the drug in the body of broiler chickens. The total body clearance of marbofloxacin in broiler chickens following single and repeated dose i.v. administration was almost similar $(0.19 \pm$ $0.02 \mathrm{~L} / \mathrm{h} / \mathrm{kg}$ ). The MRT following single and repeated dose i.v. administration were $6.78 \pm$ 0.16 and $6.63 \pm 0.15 \mathrm{~h}$, respectively in broiler chickens. In the present study, after i.v. administration low MRT value indicates that marbofloxacin remains for shorter span of time in birds due to relatively faster elimination of the drug compared to that in other animal species. However, no significant differences in elimination half-life $\left(\mathrm{t}_{1 / 2 \beta}\right)$, clearance $\left(\mathrm{Cl}_{\mathrm{B}}\right)$, volume of distribution

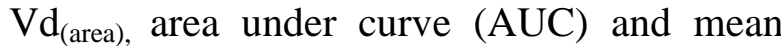
residence time (MRT) were observed after single or repeated dose i.v. administration of the drug in broiler chickens.

The mean for transfer of marbofloxacin from central to the tissue compartment $\left(\mathrm{K}_{12}\right)$, tissue to the central compartment $\left(\mathrm{K}_{21}\right)$ and the mean ratio of $\mathrm{K}_{12} / \mathrm{K}_{21}$ were $3.05 \pm 0.99 \mathrm{~h}^{-1}$, $3.11 \pm 0.80 \mathrm{~h}^{-1}$ and $0.91 \pm 0.09$,respectively after single administration and $1.87 \pm 0.20 \mathrm{~h}$ ${ }^{1}, 0.43 \pm 0.06 \mathrm{~h}^{-1}$ and $2.15 \pm 0.50$, respectively after repeated administration. The $K_{21}$ rate constant was significantly ( $p<0.01$ ) lower and mean ratio of $\mathrm{K}_{12} / \mathrm{K}_{21}$ was significantly $(\mathrm{p}<0.01)$ higher after repeated i.v. administration compare to single dose. $\mathrm{K}_{12} / \mathrm{K}_{21}$ ratio was near to one after single i.v. administration suggests that drug has no accumulation in peripheral compartment whereas the respective value was $2.15 \pm 0.50$ indicates that drug was accumulated in peripheral compartment after repeated i.v. administration. It has been established that for concentration-dependent antibacterial agents, such as fluoroquinolones, the AUC/MIC ratio is the most important efficacy predictor. The ratio of $\mathrm{AUC} / \mathrm{MIC}_{90}$ should at least $100-125 \mathrm{~h}$ for achieving maximum clinical cure and bactericidal effect (Turnidge, 1999). Single dose i.v. administration of marbofloxacin (5 $\mathrm{mg} / \mathrm{kg}$ ) in broiler chickens resulted AUC/MIC 90 ratio of 536,268 and $134 \mathrm{~h}$ at MIC values of $0.05,0.10$ and $0.20 \mu \mathrm{g} / \mathrm{mL}$ respectively.

It was concluded that after single and repeated dose i.v. administration of marbofloxacin (5 $\mathrm{mg} / \mathrm{kg}$ ) in broiler chickens, therapeutic effective concentrations were maintained up to $24 \mathrm{~h}$ post drug administration. Large volume of distribution and area under curve and higher value of $\mathrm{AUC} / \mathrm{MIC}_{90}$ indicates possibility of effectiveness of the marbofloxacin to control susceptible bacterial infections in broiler chickensat life threatening condition.

\section{Acknowledgments}

The authors are highly grateful to Junagadh Agricultural University, Junagadh, Gujarat, India for providing funds, research and animal facilities to undertake the research work.

\section{References}

Aboubakr, M. and Abdelazem, M. A. 2015. Pharmacokinetics of marbofloxacin in Japanese quails (Coturnix japonica) after different routes of administration. Journal of American Science. 11(4): 136-142.

Anadon, A.; Martinez-Larranaga, M. R.; Diaz, M. J.; Martinez, M. A.; Frejo, M. T.; Martinez, M.; Tafur, M. and Castellano, V. J. 2002. Pharmacokinetic characteristics and tissue residues for 
marbofloxacin and its metabolite $\mathrm{N}$ desmethyl-marbofloxacin in broiler chickens. American Journal of Veterinary Research. 63:927-933.

Anonymous. 2012. $19^{\text {th }}$ Livestock Census. Ministry of Agriculture, Department of Animal Husbandry and Dairying. Government of India, New Delhi.

Baggot, J. D. 1977. Principles of drug disposition in domestic animals. The basis of veterinary clinical pharmacology. $1^{\text {st }}$ Ed., W.B. Saunders Co., Philadelphia, U.S.A. pp.144-189.

Brown, S. A. 1996. Fluoroquinolones in animal health. Journal of Veterinary Pharmacology and Therapeutics. 19:114.

Carpenter, J. W.; Hunter, R. P.; Olsen, J. H.; Henry, H.; Isaza, R. and Koch, D. E. 2006. Pharmacokinetics of marbofloxacin in blue and gold macaws (Ara ararauna). American Journal of Veterinary Research. 67(6): 947-950.

De Lucas, J. J.; Rodriguez, C.; Waxman, S.; Gonzalez, F.; Uriarte, I. and San Andres, M. I. 2005. Pharmacokinetics of marbofloxacin after i.v. and intramuscular administration to ostriches. The Veterinary Journal. 170: 364-368.

Drlica, K. and Zhao, X. 1997. DNA gyrase, topoisomerase IV, and the4-quinolones. Microbiology and Molecular Biology Reviews. 61: 377-392.

Gibaldi, M. and Perrier, P. 1982. Noncompartmental analysis based on statistical moment theory. Pharmacokinetics. $2^{\text {nd }}$ ed. MarcelDekker Inc. New York. pp. 409-417.

Goudah A. and Hasabelnaby S. 2010. The disposition of marbofloxacin after single dose i.v., intramuscular and oral administration to Muscovy ducks. Journal of Veterinary Pharmacology and Therapeutics. 34:197-201.
Gouvêa, R.; Santos, F. F. dos.; Aquino, M.H.C. de. and Pereira, V. L. de A. 2015. Fluoroquinolones in Industrial Poultry Production, Bacterial Resistance and Food Residues: a Review. Brazilian Journal of Poultry Science. 17(1): 1-10.

Haddad, N. S.; Pedersoli, W. M.; Ravis, W. R.; Fazeli, M. H. and Carson, R. L. 1985. Combined pharmacokinetics of gentamicin in pony mares after a single i.v. and intramuscular administration. American Journal of Veterinary Research. 46: 2004-2007.

Haritova, A. M.; Rusenova, N. V.; Parvanov, P. R.. Lashev, L. D. and, FinkGremmels, V. 2006. Integration of Pharmacokinetic and Pharmacodynamic Indices of Marbofloxacin in Turkeys. Antimicrobial Agents and Chemotherapy. 50(11): 3779-3785.

Hasan, R. A.; Ali, M. H.; Siddique, M. P.; Rahman, M. M. and Islam, M. A. 2010. Clinical and laboratory diagnoses of common bacterial diseases of broiler and layer chickens. Bangladesh Journal of Veterinary Medicine. 8(2): 107-115.

Schneider, M.; Valle, M.; Woehrle', F. and Boisrame, B. 2004. Pharmacokinetics of marbofloxacin in lactating cows after repeated intramuscular administrations and pharmacodynamics against mastitis isolated strains. Journal of Dairy Science. 87:202-211.

Shojaee, A. F. and Lees, P. 1997. Pharmacodynamic and pharmacokineticinter-relationships of antibacterial drugs. Journal of Veterinary Pharmacology and Therapeutics. 20: 14-17.

Spreng, M.; Deleforge J.; Thomas, V.; Boisramé, B. andDrugeon, H. 1995. Antibacterial activity of marbofloxacin. A new fluoroquinolone for veterinary use against canine and feline isolates. Journal of Veterinary Pharmacology and Therapeutics. 18(4): 284-289. 
Tohamy, M. A. and El-Gendy, A. A. M. Turnidge, J. 1999. Pharmacokinetics and 2013. Some pharmacokinetic aspects and bioavailability of marbofloxacin in foals. Journal of Basic and Applied pharmacodynamics of Fuoroquinolones. Drugs. 58 (Suppl. 2): 29-36. Sciences. 2: 46-50.

\section{How to cite this article:}

Patel, H. B., U. D. Patel , C. M. Modi and Bhadarka, D. H. 2018. Pharmacokinetics of Marbofloxacin Following Single and Repeated Dose Intravenous Administration in Broiler Chickens. Int.J.Curr.Microbiol.App.Sci. 7(06): 2344-2351. doi: https://doi.org/10.20546/ijcmas.2018.706.280 